Version accepted for publication in Reviews of Geophysics 01 July 2019

\title{
Burrowing invasive species: an unquantified erosion risk at the aquatic- terrestrial interface
}

\author{
Gemma. L. Harvey ${ }^{1 *}$, Alexander. J. Henshaw ${ }^{1}$, James Brasington ${ }^{2}$, and Judy England ${ }^{3}$ \\ ${ }^{1}$ School of Geography, Queen Mary University of London, Mile End Road, E1 4NS, UK, ${ }^{2}$ Te \\ Waiora, Joint Institute for Freshwater Management, University of Waikato, New Zealand, ${ }^{3}$ \\ Environment Agency, Wallingford, England, UK
}

Corresponding author: Gemma Harvey (g.1.harvey@qmul.ac.uk)

\section{Key Points:}

- Burrowing invasive species represent a potentially significant but unquantified erosion risk at the aquatic-terrestrial interface

- Of global interest: over 100 countries, states or territories where at least one relevant example invasive species is established

- Our conceptual model demonstrates how burrows modify geotechnical, hydrological and hydraulic processes, influencing stability and erosion

\begin{abstract}
Invasive non-native species acting as 'ecosystem engineers' or 'geomorphic agents' can represent a major landscape disturbance. Quantification of their biogeomorphic impacts remains a key knowledge gap and aquatic-terrestrial transition zones may be particularly exposed to impacts. We demonstrate how burrowing invasive species represent a potentially significant but unquantified erosion risk at aquatic margins. We reveal a lack of quantitative research on geophysical impacts, despite increasing concerns over threats to waterways and flood defense infrastructure. We explore example animals of global interest, comprising crustaceans, fish, reptiles and mammals and reveal the global nature of the issue: over 100 countries, states or territories where at least one example species is established, and over 20 with 3-6 species present. We present a conceptual model for the impacts of burrows on stability and erosion at aquatic margins using established models of geotechnical, hydrological and hydraulic drivers. Burrows are hypothesized to (i) alter failure plane position, decrease failure plane length and increase failure plane angle (thereby decreasing bank shear strength); (ii) modify the spatial distribution of porewater pressure, thereby increasing subsurface flow (seepage), reducing cohesion and increasing the likelihood of slip failures at the bank face; (iii) increase turbulence and sediment entrainment at burrow entrances and (iv) alter flow resistance at the bank face. Most effects are expected to increase bank instability/erosion with the exception of (iv) which has the potential to offer protection from fluvial action. We call for
\end{abstract}


further research in these areas to quantify impacts for different environments and different invasive species.

\section{Plain Language Summary}

Animals and plants acting as 'biogeomorphic agents' can have profound impacts on earth surface processes. Numerous animals burrow into soils and sediments and this can yield a range of ecosystem benefits. The burrowing activities of some invasive or 'pest' species, however, may increase erosion risks and aquatic environments are particularly vulnerable to such impacts. Our study explores examples of burrowing invaders of global interest that have potential to pose an erosion risk to the banks and margins of rivers, lakes, ponds, marshes, estuaries and artificial drainage and flood defense infrastructure. We identify over 100 countries, states or territories with at least one example species present, and 20 with three or more burrowing invaders. There is no established framework for assessing the erosion risk from burrows, so we use existing theory from geophysics to explore the different ways in which these species may generate erosion at the margins of aquatic environments.

\section{Introduction}

The term 'ecosystem engineer' describes plants and animals that cause physical state changes in biotic or abiotic materials, either via their own physical structures or by transforming living or nonliving materials (Jones et al., 1994). The effects of ecosystem engineers on the environment is profound: they initiate, modify and maintain habitats and modulate resource flows in all ecosystems on earth (Jones et al., 1994). A subset of ecosystem engineers, referred to as 'geomorphic agents' (Butler, 1995), 'geomorphic engineers' or 'biogeomorphic agents' (Fei et al., 2014) alter earth surface processes and landforms at scales ranging from individual sediment grains to entire landscapes (Reinhardt et al., 2010; Bertoldi et al., 2011; Rice et al., 2012). Biogeomorphic agents may construct new landforms (bioconstruction), break down and fractionate soils and sediments e.g burrowing or reduce protection from erosion e.g. herbivory, (bioerosion), disturb and rework soils and sediments (bioturbation) and offer protection from erosion of weathering (bioprotection), see Naylor et al. (2010), Fei et al. (2014) and Davidson et al. (2018). As a result, these organisms can increase habitat complexity, and potentially biodiversity (Crooks, 2002), and can be used to promote the recovery of degraded environments (Byers et al., 2006; Polvi and Sarneel, 2017; Bailey et al., 2018).

Invasive species acting as ecosystem engineers and biogeomorphic agents have been identified as a special case (Crooks, 2002; Harvey et al., 2011; Fei et al., 2014; Davidson et al., 2018). While biological invasion is a natural process, species introductions (whether deliberate or accidental) have generated unprecedented increases in the rate of species invasions globally (Seebens et al., 2016) as well as changes in the nature and pathways of invasions (Crooks, 2002). These trends are expected to persist (Seebens et al., 2016). For many species, effective eradication strategies remain elusive (Stebbing et al., 2012) and indeed may be inappropriate within the context of global change and novel ecosystems (Hobbs et al., 2011). There is lively debate around the 'vilification' of nonnative and invasive species, the use of value-laden terminology (e.g. 'alien' and 'invasive'), the appropriateness of distinctions between non-native and native species in a rapidly changing planet and the suitability of existing management responses. These issues are illustrated by the 
debate between Davis et al. (2011) and Simberloff et al. (2011) and in the recent synthesis by Boltovsky et al. (2018) and we refer the reader to these sources for further information. Here, we recognize a non-native species as that which is living outside its native distributional range as a result of intentional or accidental dispersal by human activities (sometimes referred to as 'exotic' or 'introduced'; UN Convention on Biological Diversity, 2019). 'Invasive species' generally refers to those non-native species that have the ability to spread and cause damage to the environment, the economy and human health (GBNNSS, 2019; Russell, 2012). We recognize that non-native species do not necessarily become invasive, that invasive species can have positive, neutral and negative effects on the invaded landscape and ecosystem, and that many have mixed impacts (Boltovskoy et al., 2018). Native species may also be referred to as invasive or 'pest' species when environmental pressures result from the rapid dominance of a species (Valery 2013) or where their activities come into conflict with people, property or infrastructure (Bayoumi and Meghuid, 2011). We also recognize that invasive species do not possess ill intent and that their impacts have fundamentally been generated by the human activities that have facilitated their spread into nonnative ranges. Notwithstanding the important epistemological issues, there is substantial and increasing evidence that many invasive species are capable of altering ecosystems and geophysical processes in ways that may generate environmental, economic and societal risks, at least within the context of current approaches to environmental conservation and management (Pimental et al., 2001; Gallardo et al., 2016). Irrespective of the suitability of management responses, improved understanding of the biogeomorphic impacts of invasive species is required to advance knowledge of biogeomorphology and invasion ecology and support environmental management (Fei et al., 2014).

While the direct biogeomorphic impacts of invasive species are not unique in character, they can have profound geophysical effects that are disproportionate to their biomass and are more likely to lead to major geomorphic changes and stresses capable of inducing a landscape phase-state shift (Fei et al., 2014; Butler et al., 2018). Such impacts are possible since invasive species may be less constrained by factors that would limit their abundance in native habitats (Wolff, 2002), can be present in extremely high densities, and may exhibit behaviors and destructive traits that are not exhibited in the native range (e.g. Holdich, 1999). While some invasive species can generate increased habitat complexity and biodiversity, exotic animals in particular have been linked with disturbances that destroy physical structure and reduce heterogeneity in invaded landscapes (Crooks, 2002). Transitional areas between terrestrial and aquatic systems including fluvial systems, wetlands and marshes are highly connected within the landscape both laterally at the aquatic-terrestrial interface and longitudinally via the catchment-coast continuum, and have been identified as particularly exposed to the biogeomorphic impacts of invasive species (Moorhouse and Macdonald, 2015; Fei et al., 2014). Despite these attributes, quantification of the biogeomorphic impacts of invasive species remains a key knowledge gap.

Bioturbating activities, such as burrowing, frequently account for major effects in aquatic systems (Fei et al., 2014). Many terrestrial and aquatic species excavate burrows for defensive, reproductive or refuge purposes (Haussman, 2017) and burrowing species can generate diverse ecosystem benefits and services, such as contributions to nutrient cycling, climate and water regulation and pollution remediation (Wilkinson et al., 2009; Blouin et al., 2013). Burrowing 
invasive and 'pest' species, however, have the potential to increase erosion risk at aquatic margins for the reasons outlined above. This risk remains unquantified, but increasing reports of damage to natural and artificial drainage channels suggests burrowing invaders and native pests represent a significant and growing threat to waterways and flood defense infrastructure (e.g. Hoover et al., 2004; Panzacchi et al., 2007; Ferriter et al., 2008; Sementelli et al., 2008; Nico et al., 2009; Orlandini et al., 2015; Davidson et al., 2018) and historic waterside landmarks (e.g. Telegraph Reporters, 2016; BBC News, 2018). Improved understanding of the nature and extent of this risk is therefore urgently required to inform the effective and sustainable management of invaded systems.

This paper aims to demonstrate how burrowing invasive species alter geophysical processes and represent an erosion risk to aquatic margins in invaded landscapes. We highlight the lack of existing research into their impacts and identify example species of current concern at the global level. We then present a conceptual model which hypothesizes how burrows may influence erosion risk by modifying geotechnical, hydrological and hydraulic processes in river banks and indicate the relevance of these processes for other types of aquatic margin (e.g. lake margins, estuaries)

\section{Burrowing invasive species: the knowledge gap}

Numerous burrowing species have been introduced to aquatic ecosystems through a range of pathways including aquaculture, the aquarium and exotic pet trade, commercial shipping and the fur trade (Carter \& Leonard, 2002; Kern, 2004; Nico et al., 2009; Herborg et al., 2003). Burrow excavation by invasive species occurs in a number of environments along the catchment to coast continuum, including the banks of natural and artificial channels, lake margins, salt marsh edge and creek habitats, and in and around flood defense structures including earthen dams, embankments/ levees and flood walls (see Figure 1). Some invasive animals have been observed to burrow in both native and invaded ecosystems (e.g. armoured catfish; Nico et al., 2009), usually for reproductive and/or refuge purposes (see Table 1), while for others burrowing appears to be a behavior unique to invaded habitats and motivations are less clear (e.g. signal crayfish; Guan, 1994; Holdich, 1999). Burrowing habits have been linked to the invasiveness of some aquatic species, by contributing to increased environmental tolerance and protection from predation (Barbaresi et al., 2004).

Geomorphological impacts of burrowing occur at different spatio-temporal scales, ranging from the excavation of the burrow itself (i.e. an instantaneous, low magnitude sediment input), to wider impacts on bank instability and erosion across impacted bank faces and sites (potentially higher magnitude inputs over longer timescales) (Guan, 1994; Holdich, 1999; Angeler et al., 2001; Faller et al., 2016). These impacts have the potential to generate catchment scale sediment management issues, depending on the magnitude of sediment inputs and system connectivity (Harvey et al., 2011). Davidson et al. (2018) present a modified version of Parker et al.'s (1999) model for understanding and quantifying the impacts of invasive non-native species, focusing on the impact of bioeroders (including burrowing animals). The model proposes that the impacts of bioeroders, $I_{B}$ can be expressed as a function of the geographical range of the species $(\mathrm{R})$, the local abundance (A), and the per capita effects (E): $I_{B}=\mathrm{R} \times \mathrm{A} \times \mathrm{E}$, mediated by the characteristics of the substrate exposed to bioerosion and influenced by the nature of the system and environmental change 
(Davidson et al., 2018) and by variations in the nature of relationships between R, A and E (Parker et al., 1999). In the case of burrowing species, burrow dimensions generally reflect body size, since it is not energetically efficient to construct burrows larger than the minimum requirement, resulting in a positive correlation between body size and burrow volume (Haussman, 2017; Figure 1). Magnitude-frequency relationships, however, are important: smaller species occur in greater numbers and may dig more excavations per individual per year, meaning that overall sediment removal rates may exhibit a negative correlation with body size (Haussman, 2017). The potency of smaller and less conspicuous animals such as aquatic invertebrates, therefore, has the potential to rival that of larger and more visible species such as mammals.

Our literature review is not exhaustive, but provides a selection of example invasive species with published burrowing impacts. Burrowing invaders include crustaceans (crayfish, crabs, isopod), fishes (armoured catfish), reptiles (iguana) and mammals (the semi-aquatic rodent 'coypu' or 'nutria'; Myocastor coypus; Table 1). Native mammals such as muskrats, beavers, porcupines, badgers and foxes are also sometimes considered 'pest' species when their burrowing habits cause damage to flood control structures (Federal Emergency Management Agency, 2003; Orlandini et $a l ., 2015)$. The conceptual model we present in section 4 is equally applicable to such cases and to terrestrial animals (in addition to aquatic and semi-aquatic species) that construct burrows at aquatic margins. Notably, we found that reports of burrowing impacts were largely confined to biological or ecological scientific journals or 'grey literature' (reports from government departments and academic/ research institutes). This reflects the fact that the burrowing impacts of invasive species tend to be reported as one of a number of detrimental ecosystem impacts, rather than the research focus in the majority of sources. We identified six publications that focus directly on quantifying the impact of invasive burrowers on slope stability or erosion at aquatic margins, but all of these linked burrowing with increased instability and/or erosion (Talley et al., 2000; Rudnick et al., 2005; Davidson and Riviera, 2010; 2012; Orlandini et al., 2015; Aman and Grimes, 2016; Faller et al., 2016).

Table 1 Impacted habitats and invasive range for example burrowing invasive animals of global interest, together with their burrowing behaviour and burrow characteristics. Bold numbers for invasive range show total number of countries/states/territories with established populations and superscript numbers show numbers of countries/states/territories where these have been amalgamated into regions for brevity (sources: GISD, 2019; DAISIE, 2019; NOBANIS, 2019). Data on burrowing behavior and burrow characteristics are derived from reports from both invasive and native ranges. 


\begin{tabular}{|c|c|c|c|c|c|c|c|c|c|c|c|c|c|}
\hline & $\begin{array}{l}\frac{.}{0} \\
\text { कँ }\end{array}$ & Habitat & $\begin{array}{c}\text { Invasive range } \\
\text { (no. countries/ } \\
\text { territories }\end{array}$ & $\begin{array}{c}\text { Burrowing } \\
\text { life } \\
\text { stage }\end{array}$ & $\begin{array}{l}\text { Body } \\
\text { length } \\
\text { or } \\
\text { *carapace }^{\text {width }(\mathrm{cm})}\end{array}$ & $\begin{array}{l}\text { Burrow } \\
\text { function }\end{array}$ & $\begin{array}{l}\text { Bank/ } \\
\text { margin } \\
\text { type }\end{array}$ & $\begin{array}{c}\text { Burrow } \\
\text { architecture }\end{array}$ & $\begin{array}{l}\text { Burrow } \\
\text { position }\end{array}$ & $\begin{array}{c}\text { Burrow } \\
\text { entrance } \\
\text { shape }\end{array}$ & $\begin{array}{l}\text { Burrow } \\
\text { depth }(\mathrm{m}) \\
\text { range, } \\
\text { *mean or } \\
+ \text { max }\end{array}$ & $\begin{array}{l}\text { Burrow } \\
\text { density } \\
\text { Areal } \\
\left.\text { (per } \mathrm{m}^{2}\right) \\
\text { or *Linear } \\
\text { (per } \mathrm{m})\end{array}$ & Refs \\
\hline \multirow{4}{*}{ 䍃 } & $\begin{array}{l}\text { s. } \\
\text { o } \\
\text { s. } \\
0\end{array}$ & $\begin{array}{l}\text { Pond/lake } \\
\text { River } \\
\text { Drainage } \\
\text { channel } \\
\end{array}$ & 17 (Europe $^{18}$ ) & Adults & $9-12$ & Reproduction & Silt/clay & $\begin{array}{l}\text { Tunnel } \\
2 \text { entrances }\end{array}$ & $\begin{array}{l}\text { Below } \\
\text { water } \\
\text { surface }\end{array}$ & $\begin{array}{l}\text { Circular/ } \\
\text { D shaped }\end{array}$ & $\begin{array}{c}\sim 0.1 \text { (note } \\
\text { value is for } \\
\text { vertical } \\
\text { burrow) }\end{array}$ & & $\begin{array}{l}\text { Momot (1988); } \\
\text { Holdich and Black } \\
\text { (2007); Kouba et al. } \\
(2016) \\
\end{array}$ \\
\hline & $\begin{array}{l}\frac{2}{5} \\
0 \\
0\end{array}$ & $\begin{array}{l}\text { Wetland } \\
\text { Pond/lake } \\
\text { River }\end{array}$ & $\begin{array}{l}32 \text { (Canada', } \text { Europe }^{3} \text {, } \\
\left.\text { Africa }^{1}, \text { USA }^{27}\right)\end{array}$ & Adults & 13 & $\begin{array}{l}\text { Refuge } \\
\text { Reproduction }\end{array}$ & $\begin{array}{l}\text { Earth, clay, } \\
\text { silt }\end{array}$ & $\begin{array}{l}2 \text { entrances, } \\
\text { complex }\end{array}$ & $\begin{array}{l}\text { Below or } \\
\text { above } \\
\text { water } \\
\text { surface }\end{array}$ & & $1.0+$ & & $\begin{array}{l}\text { GISD, Hazlett et al. } \\
\text { (1974); Momot (1988); } \\
\text { Godfrey and Espino } \\
(2009)\end{array}$ \\
\hline & 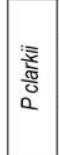 & $\begin{array}{l}\text { Wetland } \\
\text { Pond/lake } \\
\text { River } \\
\text { Rice paddy }\end{array}$ & $\begin{array}{l}\text { 46 (Africa', Caribbean }{ }^{1} \text {, } \\
\text { China, Central America }^{2} \text {, } \\
\text { Europe }^{12} \text {, Georgia, Israel, } \\
\text { Japan, Mexico, } \\
\text { Phillippines, South } \\
\text { America }^{3} \text {, Taiwan, USA }{ }^{16} \text { ) }\end{array}$ & $\begin{array}{l}\text { Immature/ } \\
\text { juveniles }\end{array}$ & $5.5-12$ & \begin{tabular}{|l|} 
Protection \\
from \\
dehydration \\
Refuge \\
Reproduction
\end{tabular} & $\begin{array}{l}\text { Silt/clay } \\
\text { dominated }\end{array}$ & $\begin{array}{l}\text { Simple/complex } \\
\text { Tunnel/complex } \\
\text { 'Chimney'l } \\
\text { mud plug }\end{array}$ & $\begin{array}{l}\text { Around } \\
\text { water } \\
\text { surface }\end{array}$ & & $\begin{array}{c}0.28-0.58 \\
4.2+\end{array}$ & $0.01-6.3$ & $\begin{array}{l}\text { Correira and } \\
\text { Ferreira (1995); } \\
\text { Bararesi et al. (2004); } \\
\text { Loureiro et al. (2015) }\end{array}$ \\
\hline & 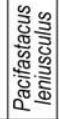 & $\begin{array}{l}\text { Pond/lake } \\
\text { River }\end{array}$ & $\begin{array}{l}17 \text { (Europe }{ }^{16} \text { and } \\
\text { Japan) }\end{array}$ & Unknown & $12-16$ & Unknown & $\begin{array}{l}\text { Cohesive } \\
\text { (silt/earth) }\end{array}$ & $\begin{array}{l}\text { Simple and } \\
\text { complex }\end{array}$ & $\begin{array}{l}\text { Around } \\
\text { water } \\
\text { surface }\end{array}$ & $\begin{array}{l}\text { Oval with } \\
\text { flat base }\end{array}$ & $0.1-0.5$ & $2.8-5.6^{*}$ & $\begin{array}{l}\text { Bubb et al. (2002); } \\
\text { Guan (1994); } \\
\text { Harvey et al. (2011), } \\
\text { Roberts (2012) }\end{array}$ \\
\hline 윤 & 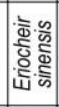 & Estuary & $\begin{array}{l}31 \text { (Canada }^{2}, \text { Europe }^{19}, \\
\left.\text { Iran, Russia, USA }{ }^{8}\right)\end{array}$ & $\begin{array}{l}\text { Mainly } \\
\text { juveniles }\end{array}$ & $5-10^{*}$ & $\begin{array}{l}\text { Refuge } \\
\text { protection } \\
\text { from } \\
\text { dessication }\end{array}$ & Silt, sand & $\begin{array}{l}\text { Simple and } \\
\text { complex }\end{array}$ & $\begin{array}{l}\text { Between } \\
\text { high and } \\
\text { low tide } \\
\text { lines }\end{array}$ & Elliptical & $0.31^{*}-0.44^{*}$ & $\begin{array}{l}20^{*} \\
30\end{array}$ & $\begin{array}{l}\text { Rudnick et al. (2000); } \\
\text { Rudnick et al. (2005) }\end{array}$ \\
\hline $\begin{array}{l}\text { 믐 } \\
\text { 음 }\end{array}$ & 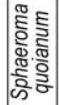 & Estuary & $2\left(\mathrm{USA}^{2}\right)$ & Adults & up to 1.5 & Filter feeding & $\begin{array}{l}\text { Peat, silt, } \\
\text { clay }\end{array}$ & $\begin{array}{l}\text { Vermiform } \\
\text { Single/complex } \\
\text { ('galleries') }\end{array}$ & & Circular & $0.02^{*}$ & $778^{*}$ & $\begin{array}{l}\text { Talley et al. (2001); } \\
\text { Davidson and Riviera } \\
\text { (2012) }\end{array}$ \\
\hline$\frac{5}{i \frac{5}{4}}$ & 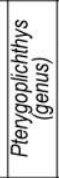 & $\begin{array}{l}\text { Pond/lake } \\
\text { River } \\
\text { Drainage } \\
\text { channel }\end{array}$ & \begin{tabular}{|l|}
19 (Bangladesh, \\
Caribbean', Central \\
America', India, \\
Indonesia,, Japan, \\
Malaysia, Philippines, \\
Singapore, Thailand, \\
Taiwan, Vietnam, USA
\end{tabular} & $\begin{array}{l}\text { Adult } \\
\text { males }\end{array}$ & $30-70$ & Reproduction & Silt/clay & $\begin{array}{l}\text { Single } \\
\text { Tunnels } \\
\text { Colonies }(\sim 12) \\
\\
\text { (2 openings/ } \\
\text { chambers - rare }\end{array}$ & $\begin{array}{l}\text { Around } \\
\text { water } \\
\text { surface }\end{array}$ & $\begin{array}{l}\text { Triangular/ } \\
\text { arched/ } \\
\text { oval }\end{array}$ & $\begin{array}{c}0.20-1.30 \\
0.78^{*}\end{array}$ & $0.5-3.9$ & $\begin{array}{l}\text { Nico et al. (2009); } \\
\text { Van den Ende (2014) }\end{array}$ \\
\hline 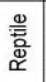 & ఇָำ & $\begin{array}{l}\text { Pond/lake } \\
\text { Drainage } \\
\text { channel }\end{array}$ & $\begin{array}{l}10 \text { (Caribbean }^{6} \text {, Europe } \\
\text { Fiji, } \\
\text { USArks and Caicos, } \\
\text { USA }\end{array}$ & $\begin{array}{l}\text { Adult } \\
\text { females }\end{array}$ & up to 150 & $\begin{array}{l}\text { Reproduction } \\
\text { Refuge }\end{array}$ & Earth & $\begin{array}{l}\text { Single tunnels } \\
\text { can extend to } \\
\text { complex systems }\end{array}$ & \begin{tabular}{|l|} 
Steep \\
banks or \\
terrestrial
\end{tabular} & Circular & $0.3-2.4$ & $0.2^{*}$ & $\begin{array}{l}\text { Sementelli et al. } \\
\text { (2008); Rand and } \\
\text { Dugan (1983) }\end{array}$ \\
\hline 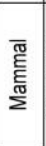 & 总 & $\begin{array}{l}\text { Wetland } \\
\text { Pond/lake } \\
\text { Drainage } \\
\text { channel }\end{array}$ & $\begin{array}{l}48 \text { (Africa }^{1} \text {, Armenia, } \\
\text { Azerbaijan, Canada }^{3}, \\
\text { Europe }^{19}, \text { Georgia, Israel, } \\
\text { Japan, Russia, Tajikistan, } \\
\text { USA }^{16} \text { ) }\end{array}$ & Adults & $\begin{array}{c}40-60 \\
(70-105 \\
\text { including tail) }\end{array}$ & \begin{tabular}{|l|} 
Refuge \\
protection \\
from thermal \\
extremes \\
Reproduction
\end{tabular} & \begin{tabular}{|l|}
$45-90$ \\
degree \\
bank \\
slope, \\
vegetated
\end{tabular} & $\begin{array}{l}\text { Simple/complex } \\
\text { Tunnel/chamber }\end{array}$ & $\begin{array}{l}\text { Below } \\
\text { water } \\
\text { surface }\end{array}$ & Oval & $1.0-5.0$ & & $\begin{array}{l}\text { Baroch et al. (2002); } \\
\text { https://wdfw.wa. } \\
\text { gov/living/nutria. } \\
\text { html\#facts; } \\
\text { Sheffels et al. (2007) } \\
\text { Sofia et al. (2017) }\end{array}$ \\
\hline
\end{tabular}

Although native burrowing animals are numerous (Haussman, 2017), there is no existing theoretical framework identifying the geotechnical, hydrological and hydraulic impacts of burrows that can be applied to burrowing species. Detailed understanding of the mechanics of burrowing is largely limited to hypothesized generalizations for idealized solids and experimentation with analog materials, failing to account for the complex and heterogeneous characteristics of natural sediments (Dorgan, 2015). Characterizing burrow-induced failure in natural substrates is therefore a critical knowledge gap requiring the development of new methods and approaches (Dorgan, 2015).

\section{Example species of global interest}

Crustaceans are the most successful aquatic invaders across the globe, accounting for 53\% of invasive species in European freshwater ecosystems compared to $12 \%$ of native species (Hanfling et al., 2011) and 28\% of coastal invasions in North America (Ruiz et al., 2011). They are the most widespread invasive aquatic organisms and are considered to be the most detrimental in terms of impacts on ecosystem services (Vila et al., 2010). Several crustacean species of global interest are known to dig burrows into river banks, including a number of freshwater crayfish: spiny cheek crayfish (Orconectes limosus), virile crayfish (Orconectes virilis), red swamp crayfish 
(Procambarus clarkii) and signal crayfish (Pacifastacus leniusculus). For some species the biological motivation for burrowing behaviour has been established (e.g. reproduction; P. clarkii; Loureiro et al., 2015) while for others burrowing appears to be a characteristic unique to invaded ecosystems and motivations are less clear (e.g. P. leniusculus, Guan, 1994; Holdich, 1999; Table 1). Crayfish burrow architecture is often simple, comprising single openings with tunnels enlarging to a terminal chamber, although more complex architectures with multiple entrances have been observed (Correia \& Ferreira, 1995). Evidence suggests that burrow construction is favored in fine, moist sediment; characteristics that also make vacant burrows more susceptible to collapse, potentially leading to further construction elsewhere (Barbaresi et al., 2004; Figure 1a). Field observations at individual sites have linked invasive crayfish burrowing with increased bank erosion and sediment delivery (Guan, 1994; Holdich, 1999; Angeler et al., 2001) and a recent extensive, multi-catchment study identified a statistical association between invasive crayfish burrows and bank erosion (fluvial action and mass failure processes) beyond the scale of individual burrows (Faller et al., 2016). Faller et al. (2016) also reveal a tendency for burrows to be excavated on bare, eroding banks on the outside of meander bends. These are areas already exposed to erosional processes indicating potential for burrowing to accelerate erosion rates.

Invasive crabs and isopods generate similar effects in estuarine and coastal margins. Perhaps the most widely-reported are Chinese mitten crabs (Eriocheir sinensis) which have spread across Europe and northern California via the transport of larvae and juveniles in the ballast water of commercial vessels (Herborg et al., 2003). Their catadromous life cycle means that in addition to rapidly colonizing coastal and estuarine areas, E. sinensis can make significant migrations inland (Clark et al., 1998; Herborg et al., 2005). Burrows are generally excavated by juveniles following migration into brackish channels, for purposes of refuge during moulting and protection from dessication (Rudnick et al., 2000; Bouma \& Soes, 2010). The highest dispersal rates (> $400 \mathrm{~km}$ per year) have been observed along coastlines, but upstream or inland spread can also been rapid with rates of up to $49 \mathrm{~km}$ per year reported in the UK (Herborg et al., 2005). E. sinensis burrow entrances are elliptical, reflecting the flat oval-shaped bodies of the crabs (Rudnick et al., 2003) and architectures can range from single tunnel-chamber systems containing one crab, to more complex burrow systems with multiple entrances and tunnels containing multiple crabs, with the latter most likely reflecting reuse over longer time periods by multiple year classes (Rudnick et al., 2003). As a result, burrow volume can vary by an order of magnitude, for example between $10^{2}$ and $10^{3} \mathrm{~cm}^{3}$ (Rudnick et al. 2005) and burrow densities of up to 30 per $\mathrm{m}^{2}$ have been reported (Rudnick et al., 2000). E. sinensis burrows were linked with erosion as early as the 1930s in Germany (Panning, 1938) and erosion concerns have been raised more recently in the USA, UK and continental Europe (Herborg et al., 2003; Rudnick et al., 2005, Bouma \& Soes, 2010). 

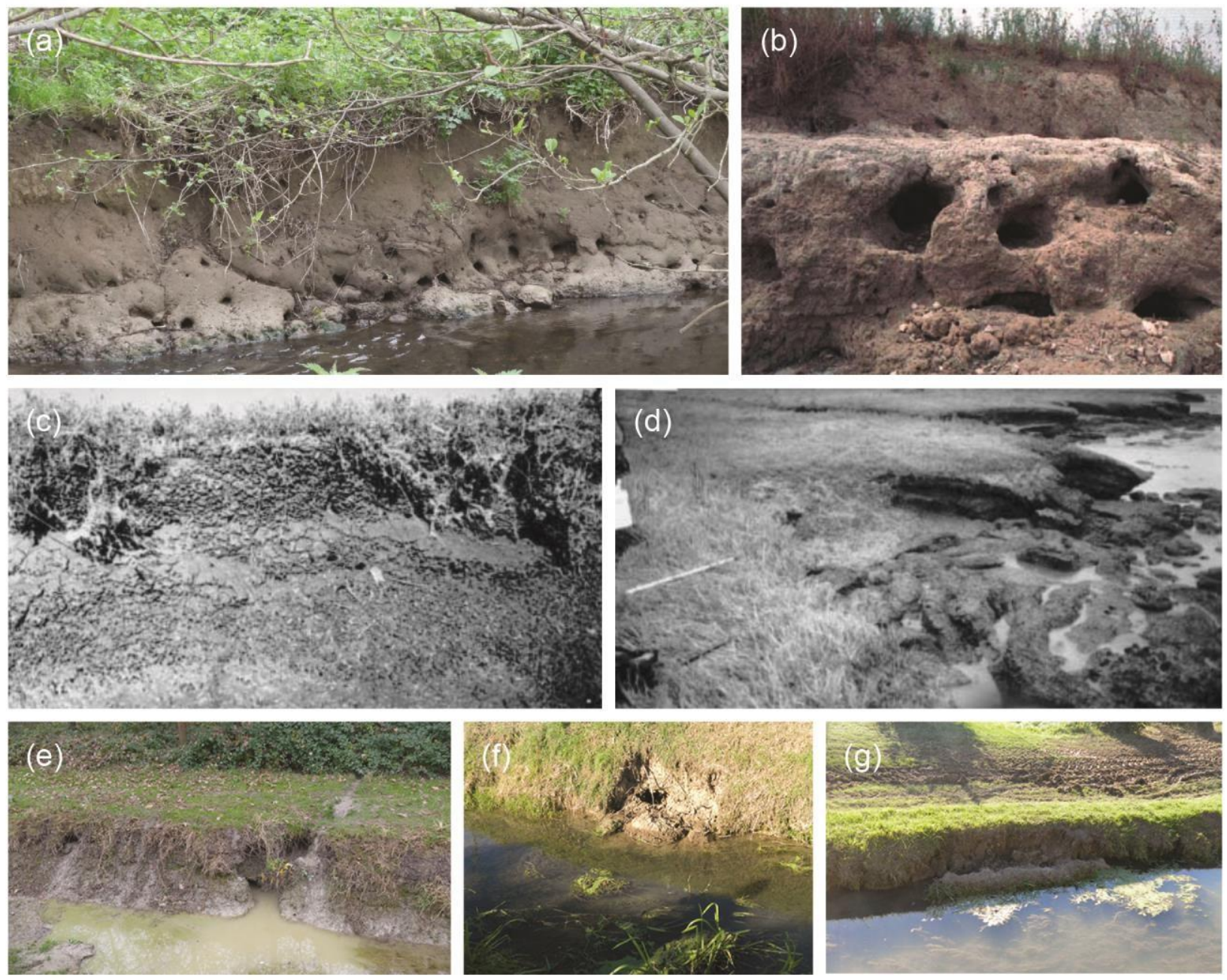

Figure 1 Examples of invasive species burrows in different types of aquatic margin: (a) $P$. leniusculus burrows on the River Enbourne, UK; (b) Pterygoplichthys sp. burrows on the San Antonio River, Texas, USA (reproduced from Hoover et al., 2004); (c) Sediment loosened by extensive burrowing activity of $S$. quoianum and (d) collapse of marsh surface linked with $S$. quoianum burrowing, both from Paradise Creek, San Diego Bay, USA (both reproduced from Talley et al., 2001, with permission from Springer Nature); and (e-g) M. coypus burrows and associated erosion on drainage channels in northern Italy (reproduced from Sofia et al., 2016, with permission from John Wiley \& Sons).

Another invasive crab species, the naturally aggressive and territorial European green crab (Carcinus maenas) is invasive in North America, Australia, South Africa, South America and Asia (GISD, 2019). Concerns over salt marsh erosion have been raised for some invaded areas as a result of burrowing into shore banks (Wallentinus \& Nyberg, 2007; Aman \& Wilson Grimes, 2016). Native burrowing crabs (Sesarma reticulatum) have also been linked with high magnitude peat displacement from New England salt marshes as a result of predator depletion and associated population density increases of $\sim 400 \%$ (Coverdale et al., 2013), illustrating the potential for similar effects from native species that become invasive. Interestingly, in this case $C$. maenas invasion assisted cordgrass recovery by reducing $S$. reticulatum functional density and herbivory through 
burrow occupation and other effects (Coverdale et al., 2013). Smaller animals can also have pronounced effects. For example, the Australasian isopod (Sphaeroma quoianum) has colonized at least 15 estuaries on the Pacific coast of North America (Davidson, 2008), creating dense networks of interconnected burrows in the peat and mud banks of tidal creeks and marsh edges (Talley et al., 2001; Davidson, 2008; Figure 1c, d). While adult body size is small (11-13 mm), $S$. quoianum can occur in very high densities and a population of 100000 adults burrowing for two months has the potential to remove approximately 176L of salt marsh bank (Davidson \& Rivera, 2012). Infested sites have been associated with higher lateral salt marsh erosion rates (increases of up to $300 \%$ ) and greater incidence of undercutting, calving and slumping (Davidson \& Rivera, 2010).

Fewer invasive fish are known to excavate burrows, but suckermouth armoured catfishes (Siluriformes: Loricariidae) or loricariids, have the potential to contribute to instability and erosion at aquatic margins. Loricariids are a large and diverse group, native to South America, Panama and Costa Rica (Lienhart et al., 2013). Many species are popular aquarium fishes and three genera (Hypostomus, Pterygoplichthys and Ancistrus), have been introduced outside their native ranges via the aquarium trade and established non-native populations across the globe (Nico et al., 2009; Lienhart et al., 2013). Both Hypostomus and Pterygoplichthys are known to excavate burrows (Nico et al., 2009), primarily for nesting and spawning, but reports generally focus on Pterygoplichthys (including Pterygoplichthys anisitsi; $P$. disjunctivus; $P$. pardalis; and $P$. multiradiatus) since they also have large broods, are able to tolerate a wide range of environmental conditions (Lienhart et al., 2013) and are the most widely introduced, occurring in drainage ditches and rivers across the USA, Central America, Asia and the Caribbean (Nico et al., 2009). Adults are relatively large, measuring on average $30-50 \mathrm{~cm}$ and up to a maximum of $70 \mathrm{~cm}$ in length (Nico et al., 2009). Simple, straight, single-tunnel burrows occur in both native and invaded habitats, commonly where population densities are high and habitat suitable, and are generally aggregated into 'colonies' of up to 12 burrows (Nico et al., 2009; Figure 1b). Burrows can reach up to $1 \mathrm{~m}$ in length and may be randomly dispersed or clumped in higher density areas (van den Ende, 2014). As noted for P. leniusculus above, Pterygoplichthys appear to preferentially select locations already exposed to erosional processes as preferential burrowing sites: steep, exposed banks dominated by fine sediment (silt and clay) on the outer bends of meanders in natural channels (Nico et al., 2009; van den Ende, 2014). Burrows have been found in a range of environments, however, including lake shores, canal banks, dikes and levees (Ferriter et al., 2008) leading to concerns over erosion and undermining of structures (Hoover et al., 2004; Nico et al., 2009).

Impacts associated with burrowing reptiles have also been reported, although to a lesser degree. The green iguana (Iguana iguana) is a particular concern in south Florida where feral populations have established as a result of escape or deliberate release of animals imported as exotic pets (Kern, 2004). Burrows are excavated for nesting or refuge purposes (Krysko et al., 2007) and have been observed in the banks of canals and levees and adjacent to seawalls. Burrows are sizeable, measuring up to $0.2 \mathrm{~m}$ in width and $2.4 \mathrm{~m}$ in depth, and hence have the potential to penetrate into flood defense infrastructure to a considerable extent (Sementelli et al., 2008). As a result, I. iguana burrows have been linked with bank instability and erosion and the collapse of seawalls, and 
similar impacts have been suggested for other species including the Mexican spiny-tailed iguana (Ctenosaura pectinate) and black spiny-tailed iguana (C. similis) (Kern, 2004; Ferriter et al., 2008).

The semi-aquatic rodent Myocastor coypus (coypu or nutria), native to South America, has established feral populations across Europe, Asia, Africa and North America following introduction for fur farming (Carter \& Leonard, 2002). M. coypus excavates burrows into river banks and levees for protection from predators and thermal extremes (Hong et al., 2015). Burrows can extend for up to $5 \mathrm{~m}$ in depth and range from simple single-entrance systems to complex systems with multiple tunnels and entrances at different levels (Washington State Department of Fish and Wildlife, 2006). Burrowing activity by M. coypus has been linked to the undermining of banks and embankments on irrigation canals (Bertolino \& Genovesi, 2007; Sofia et al., 2016; Figure 1e-g) and burrow-induced collapse of weakened banks and levees has been linked to devastating flood events (Panzacchi et al., 2007; Orlandini et al., 2015). River bank management related to M. coypus has been estimated as in excess of $€ 1$ million per year in Italy (Panzacchi et al., 2007). Other mammal species, such as the North American beaver (Castor canadensis) which is invasive in Patagonia, are known to burrow but reported biogeomorphic impacts in invaded systems have, to date, focused on beaver meadow formation and how this differs from models developed for the native range (Westbrook et al., 2017). The burrowing behavior of native rodents, including muskrats, beavers, groundhogs, porcupines, badgers and foxes, has also been identified as posing a significant threat to the integrity of earthen dams and levees (Federal Emergency Management Agency, 2003; Bayoumi and Meguid, 2011; Orlandini et al., 2015).

Data on the non-native range of the example species/genera discussed above were sourced from the Global Invasive Species database (GISD, 2019), European Network on Invasive Alien Species (NOBANIS, 2019) and Delivering Alien Invasive Species Inventories for Europe (DAISIE, 2019) for species listed as 'Alien' in status and 'established' in occurrence (unless accompanying notes indicated status was uncertain). This may omit invaded areas that are reported in the literature but have not yet been added to the databases, so the map is intended to provide an indication of the global relevance of the issue rather than a comprehensive assessment of individual species distributions. In total, there are 120 countries, states or territories where at least one species of interest has established a non-native population and 24 where there are between 3 and 5 species present. Six of the species discussed have established non-native populations in the Netherlands (4 crayfish spp., E. sinensis, M. coypus) and California (2 crayfish spp., E sinensis, C. maenas, $S$. quoianum, Pterygoplichthys spp.). The number of species per country, territory or state is summarized in Figure 2 and Table 1 presents further information at species level. The most globally widespread species/genera are $M$. coypus and $P$. clarkii followed by $E$. sinensis and the Pterygoplichthys spp. Table 1 also summarizes the main types of aquatic margin affected by burrowing invasive species as identified from the literature. All species are associated with either rivers, estuaries or artificial channels (and most commonly a combination of these), and most species also occur in pond and lake habitats and/or wetlands. 


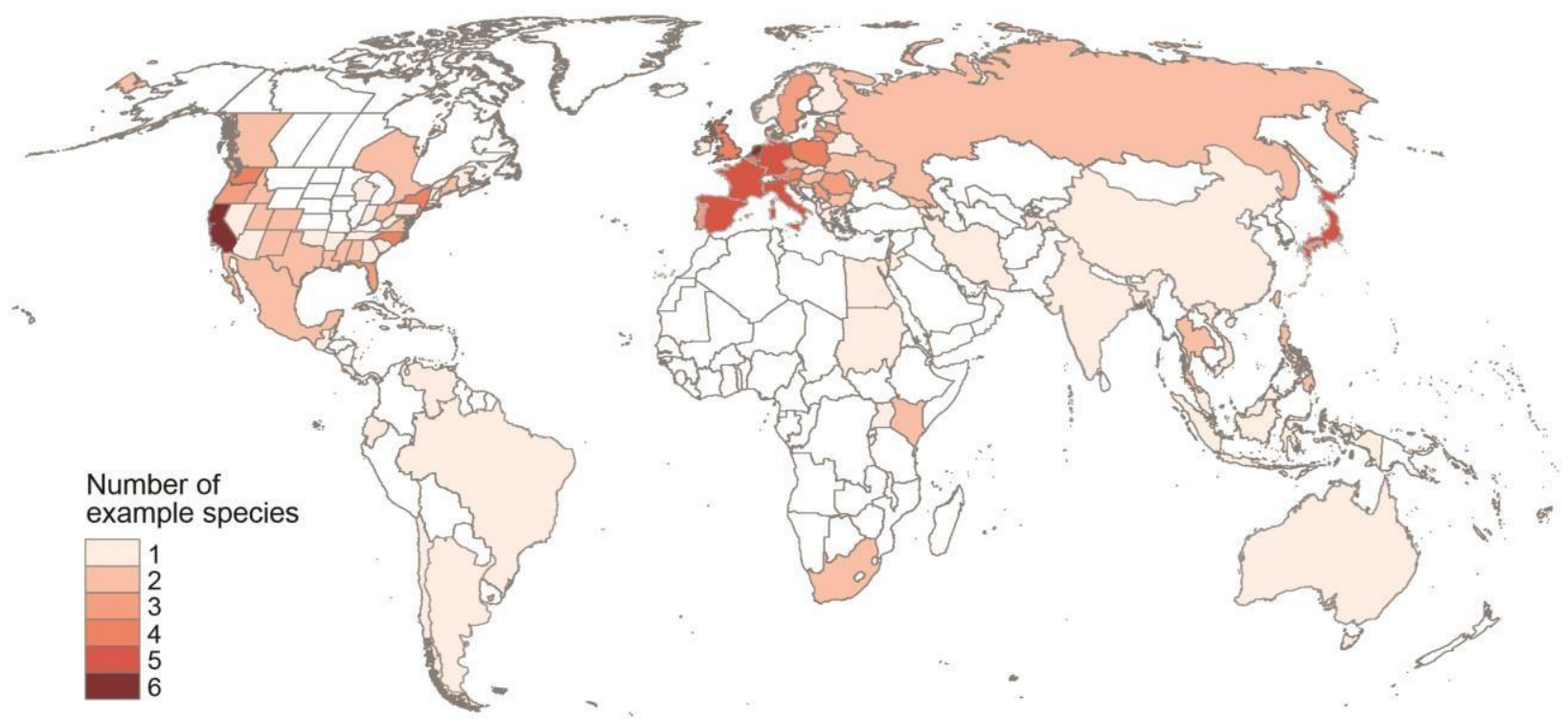

Figure 2 Map showing the number of example burrowing invasive animals discussed in the text for different countries (or states/ territories for the USA and Canada). Data sourced from GISD (2019), DAISE (2019) and NOBANIS (2019). Species included: O. limosus, O. virilis, P. clarkii, P. leniusculus, E sinensis, C. maenas, S. quoianum, Pterygoplichthys spp., I. iguana, M. coypus.

\section{A conceptual model for burrow-induced bank erosion}

The burrowing activities described above physically remove sediment from aquatic margins; primarily through the mechanism of excavation (pulling or scraping grains; Dorgan, 2015). Operating in isolation, this process will generate sediment flux from aquatic margins at a rate that is dependent on the size of burrows constructed by the species in question, its behavioral characteristics and the local population density. However, the construction of burrows by animals also has the potential to impact upon physical processes that operate on and within aquatic margins at scales much larger than an individual burrow. The following sections present a conceptual model hypothesizing how burrowing invaders will influence bank stability and erosion through geotechnical, hydrological and hydraulic effects. The primary focus is on river banks but we also indicate the relevance of each process to other types of aquatic margin. While similar mechanisms will be associated with native burrowing species, the potential for invasive species to establish high population (and burrow) densities and, hence, represent a system disturbance increases the potential extent and intensity of any impacts and, thus, the significance of any resultant conservation or management issues.

River banks retreat through a combination of fluvial (hydraulic) erosion and mass failure. Fluvial erosion refers to the dislodgement or entrainment of particles or aggregates of sediment due to the shearing action of flow at the water-sediment boundary. It occurs when forces acting to hold a particle or assemblage of particles in place (friction, interlocking and/or cohesion; Lawler et al., 1997) are overcome by those acting to mobilize the particle or assemblage of particles (lift and drag, together with the downslope component of its submerged weight; Lawler et al., 1997). Mass failure can be defined as the movement or collapse of bank material due to geotechnical instability. 
Typically, this involves failure along a discrete plane deep within the bank and its occurrence depends on the balance between the forces acting to move a unit of bank material downslope (the tangential component of its weight) and those acting to resist that movement (see above; Lawler $e t$ al., 1997). These two mechanisms are intrinsically linked, with the removal of material from the bank toe by fluvial erosion increasing the likelihood of mass failure due to an undercutting or steepening of the bank (Thorne, 1982). Eventual failure of the bank through mass failure delivers material to the bank toe which, in turn, protects the lower bank from further erosion until removal by subsequent fluvial erosion. This is referred to as basal endpoint control (Carson and Kirkby, 1972; Thorne, 1982) and is an important determinant of river bank retreat rates. Detailed understanding of how burrowing modifies these processes based on observational data is lacking but established models from soil science and fluid mechanics provide a theoretical basis upon which effects can be hypothesized. These are elaborated in the following sections.

\subsection{Geotechnical and hydrological effects of burrowing}

The shear strength of cohesive river banks under saturated conditions can be represented by the revised Mohr-Coulomb equation:

$\begin{array}{ll}S_{\mathrm{r}}=c^{\prime}+\left(\sigma-\mu_{\mathrm{w}}\right) \tan \varphi^{\prime} & \text { Equation } 1\end{array}$

where $S_{r}$ is the effective shear strength $(k P a) ; c^{\prime}$ is the effective cohesion $(\mathrm{kPa}) ; \sigma$ is the normal stress $(\mathrm{kPa}) ; \mu_{w}$ is the pore-water pressure $(\mathrm{kPa})$ and $\varphi^{\prime}$ is the effective angle of internal friction in degrees (Fredlund \& Rhardjo, 1993). The normal stress is computed by:

$\sigma=W \cos \beta$

Equation 2

where $W$ is the weight of the failure block per unit area of failure plane $\left(\mathrm{kN} \mathrm{m}^{-2}\right)$ and $\beta$ is the angle of the failure plane in degrees.

Banks will fail where the resistive strength, $S_{\mathrm{r}}$, is exceeded by the driving gravitational force, $S_{\mathrm{d}}$, as represented by:

$S_{d}=W \sin \beta$

Equation 3

where $S_{\mathrm{d}}$ is the driving gravitational force $(\mathrm{kPa}), W$ is the weight of the failure block per unit area of failure plane $\left(\mathrm{kN} \mathrm{m}^{-2}\right)$ and $\beta$ is the angle of the failure plane in degrees. The ratio between these resisting and driving forces is known as the factor of safety, with failure occurring when its value falls below unity.

The presence of burrows will modify the value of key terms in the above equations. Their concentration and extension into the bank at and below the mean water level (see Table 1) can be considered akin to fluvial undercutting at the bank toe in that it will increase the potential failure plane angle and decrease the effective friction angle (c.f. Thorne \& Tovey, 1991; Simon et al., 2000; Figure 3), decreasing the factor of safety. Furthermore, the tendency of some species (e.g. P. clarkii, M. coypus) to dig tunnels that extend towards the bank top surface (see Figure 1e) 
increases the likelihood that such burrows will act in a similar way to tension cracks. These are vertical voids that develop downwards from the ground surface some distance from the bank face due to horizontal tensile stresses generated behind steep banks and slopes (Terzaghi et al., 1996). Their presence decreases bank stability by reducing the effective length of potential failure planes (and, thus, effective cohesion), with the eventual mechanism of collapse (e.g. slip versus toppling failure) being determined by the length of the tension crack relative to the height of the bank (Darby and Thorne, 1994). Natural undercutting and tension crack development tends to occur over lengths of river bank that are significantly greater than individual burrows, and between-burrow bank material will act to maintain stability. The significance of these effects are therefore likely to be determined by the lateral extent and intensity of burrowing, together with the burrow architecture, and revised stability equations will need to be developed to aid predictions of bank failure due to the geotechnical effects of burrowing. Similar processes will operate at other aquatic margins including estuaries, marsh edges and creeks and lake shores, with the nature of failure reflecting the sediment characteristics and geometry of the bank, shore or margin.

Physical changes to the internal structure of river banks caused by animal burrows may, alone, be sufficient to cause mass failure via the mechanisms described above. The probability of mass failure is, however, likely to increase where these effects are compounded by coincident hydrological changes within the river bank. The presence of animal burrows in river banks can significantly alter the hydrological behavior of the bank. Evidence from a limited number of studies suggests that crustacean burrows modify the spatial distribution of pore-water pressure within banks (Onda \& Itakira, 1997; Xin et al., 2009). This is significant as Equation 1 shows how increased pore-water pressures can reduce the strength of banks. The occurrence of positive porewater pressures in banks during the receding limb of flood events where the water surface elevation in the channel falls rapidly has long been recognized as a cause of bank instability and erosion (Simon et al., 2000) and the presence of burrows will enable such conditions to occur at greater depths within cohesive banks than might otherwise be expected. Even in unsaturated conditions, relatively small losses of negative pore-water pressures have been shown to be capable of generating bank failures (Casagli et al., 1999; Simon \& Curini, 1998). The following modified version of the Mohr-Coulomb equation demonstrates how an increase in pore-water pressure decreases the effective stress of the soil and, thus, the soil shear strength (Darby \& Thorne, 1996; Fox \& Wilson, 2010):

$S_{\mathrm{r}}=c^{\prime}+\left(\sigma-\mu_{\mathrm{a}}\right) \tan \varphi^{\prime}+\left(\mu_{\mathrm{a}}-\mu_{\mathrm{w}}\right) \tan \varphi^{b} \quad$ Equation 4

where $S_{r}$ is the shear strength $(k P a) ; c^{\prime}$ is the effective cohesion $(\mathrm{kPa}) ; \sigma$ is the normal stress $(\mathrm{kPa})$; $\mu_{a}$ is the soil pore-air pressure $(\mathrm{kPa}), \mu_{w}$ is the pore-water pressure $(\mathrm{kPa}), \varphi^{\prime}$ is the effective angle of internal friction in degrees, and $\varphi^{\mathrm{b}}$ is the angle indicating the rate of increase in shear strength relative to matric suction (Fredlund \& Rahardjo, 1993; Simon et al., 2000).

Onda \& Itakira (1997) show that the presence of burrows modifies the location of the phreatic surface within the bank, increases the hydraulic gradient and concentrates subsurface (seepage) flow. Together, these effects have been shown to cause within-burrow erosion and the collapse of overhanging material (Onda \& Itakira, 1997). These effects can be considered akin to horizontal 
macropores (soil pipes) that develop in banks and hillslopes above water-restricting layers and act as preferential flow pathways (Hagerty, 1991a; Hagerty, 1991bFaulkner, 2006; Lindow et al., 2009; Fox \& Wilson, 2010). Concentration of subsurface flow along these pathways leads to bank undercutting, tension crack formation and eventual collapse due to mass failure (Hagerty, 1991a; Hagerty, 1991b; Fox \& Wilson, 2010). We hypothesize that animal burrows will perform a similar hydrological function during the rapid drawdown of soil moisture following high magnitude flood events, with the extension of the burrow into the bank causing elevated pore-water pressures at the lower bank face and accentuating the likelihood of slip failures at the bank face once the water level falls below the elevation of the burrow entrance (Figure 3). Under baseflow conditions, however, increased drainage of the bank associated with burrow presence may reduce antecedent near-bank face pore water pressures, reducing susceptibility to erosion during lower magnitude flow events. A similar effect has been observed in artificially drained high, steep river banks (Shields et al., 2009). Further research is needed to quantify the hydrological significance of burrows and their implications for bank stability. As with any potential geotechnical effects, the lateral extent and intensity of burrowing, together with the burrow architecture and typical position relative to the mean water level are likely to act as important determinants of the magnitude of any hydrological effect, in combination with the magnitude and frequency of water level fluctuations as determined by the hydrological regime. Similar processes will operate at other aquatic margins, but with key differences in the nature, magnitude and frequency of hydrological fluctuations associated with tidal and lentic hydrological systems. 
(a)

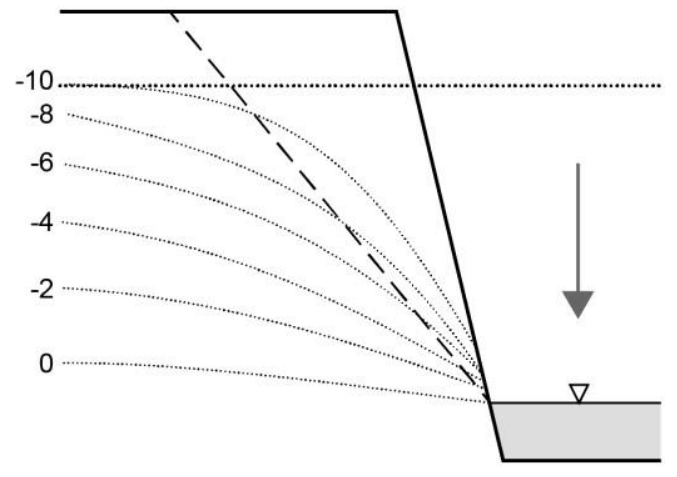

(b)

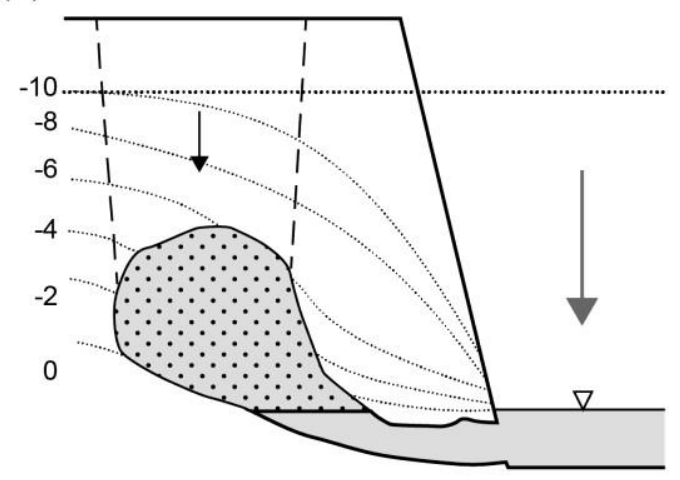

(c)

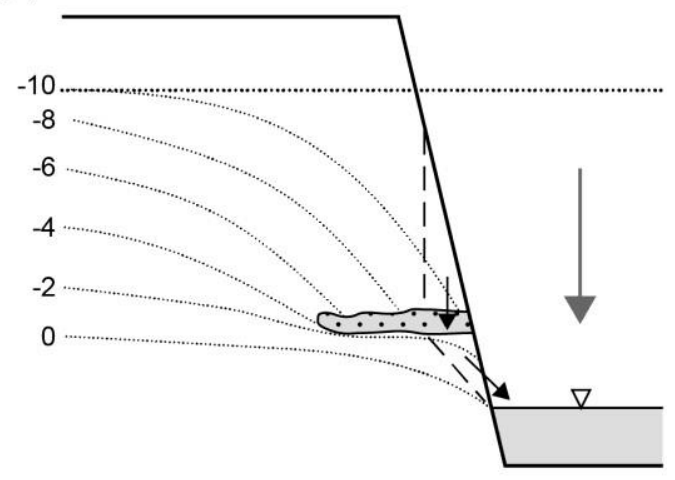

- - - - Potential failure plane

Pore water pressure

(kPA, values are indicative)

$\longrightarrow$ Failure

Drawdown following flood

Figure 3 Conceptual basis for geotechnical and hydrological effects of burrowing. Hypothesized spatial distribution of pore water pressure and position, length and angle of potential failure planes immediately following a flood event under the following scenarios: (a) a cohesive river bank without burrows; (b) the same bank burrowed by M. coypus; and (c) the same bank burrowed by $P$. leniusculus. Note: the exact hydrological response of a bank following flood drawdown will be determined by its geometry, material properties and the nature of the event. 


\subsection{Hydraulic effects of burrowing}

We hypothesize that the hydraulic effects of animal burrowing (and, thus, their potential impact on fluvial erosion at the bank face) will vary with spatial scale. At the scale of individual burrows, cavities are known to modify near-bank flow structures in open channels, for example by generating high levels of vorticity as flow passes over their leading (upstream) and trailing (downstream) edges (Ozalp et al., 2010; Jackson et al., 2015; Figure 4). Enhanced turbulence around the entrances to animal burrows (in contrast to that typically encountered on smooth bank faces) may therefore amplify the direct entrainment of particles from the surface of the bank.

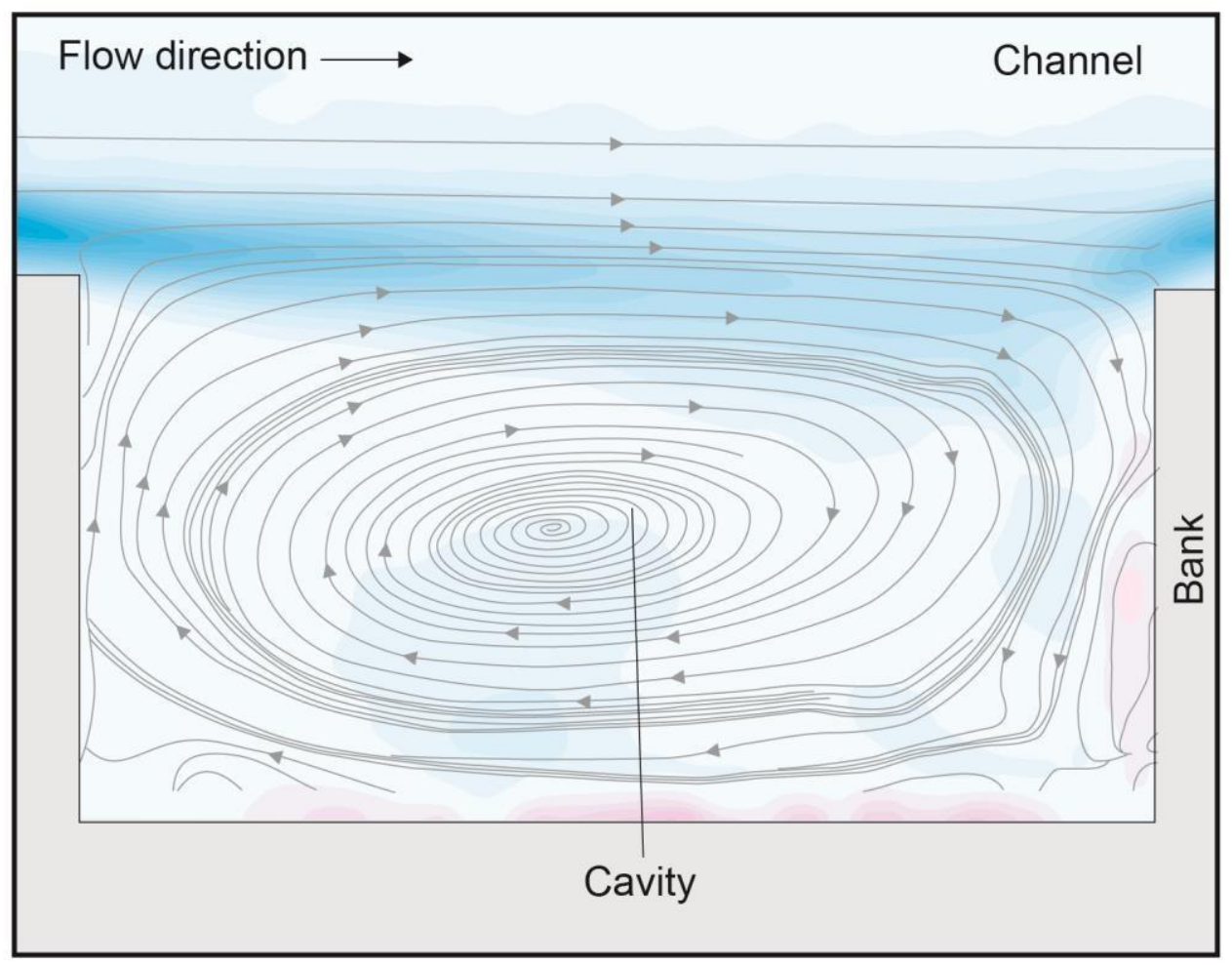

Figure 4 Conceptual basis for hydraulic effects of burrowing at the cavity scale, showing streamlines and contours for vorticity (Reynolds number $=1700$; negative values in blue, positive values in red shading). Schematized diagram based on the experimental results of Ozalp et al. (2010), with permission from Elsevier (Figures 5 and 6).

At the wider bank section scale, however, the collective effect of multiple burrows may be to reduce overall rates of fluvial erosion as a result of increased roughness. Bank erosion rates are generally quantified using an 'excess shear stress' formula, whereby the erosion rate reflects the shear stress applied by the flow in relation to an erodibility coefficient and a critical shear stress value (Rinaldi \& Darby, 2007). The total shear stress can be partitioned into 'skin friction', arising from the fluid stresses acting on the boundary and the 'drag stress' arising from the pressure differential created by flow past topographic irregularities (Kean et al., 2009). Partitioning of skin friction and form drag is critical for accurate prediction of erosion rates, but understanding of relationships between bank roughness and erosion is relatively limited and largely derived from 
laboratory experimentation due to the complexities associated with modelling the highly irregular surfaces of river banks.

For macrorough flow (where roughness elements approach the order of magnitude of channel dimensions) and under laboratory conditions, rectangular cavities can influence vertical mixing layers, wake zones, recirculation gyres, coherent structures and skin friction, with the overall effect of significantly increasing flow resistance (Meile et al., 2011). Smaller-scale topographic features characteristic of natural river banks may have similar effects. Natural banks (without burrows) are characterized by small scale topographic undulations produced by erosional processes and/or vegetation which create near-bank disturbance layers, exerting form drag that can profoundly modify flow resistance (Kean \& Smith, 2006a; 2006b; Figure 5). Such effects can be sufficient to drive periodic changes in erosion potential associated with changes in the relative magnitude of form and skin stresses through time (Leyland et al., 2015). For instance, bank failures resulting from high magnitude flows can generate complex bank geometries, increasing form drag relative to skin friction and offering protection from further erosion, while smoothing of the bank face in intervening periods of lower-magnitude flows can increase erosion potential by reducing form drag in relation to skin friction (Leyland et al., 2015). We hypothesize that the nature and magnitude of the hydraulic effect of burrows will be influenced by burrow size, shape and density. Individual or widely spaced burrows may generate localized increases in turbulence intensity and particle entrainment around burrow entrances, with burrow size and shape determining the nature of alterations to the flow field. In contrast, for banks with higher burrow densities the combined effect of multiple burrows may increase flow resistance and potentially reduce hydraulic erosion rates. Hydraulic effects of burrows are likely to be most pronounced for aquatic margins in river and tidal systems, but wind-induced turbulence in lentic systems may also be relevant.

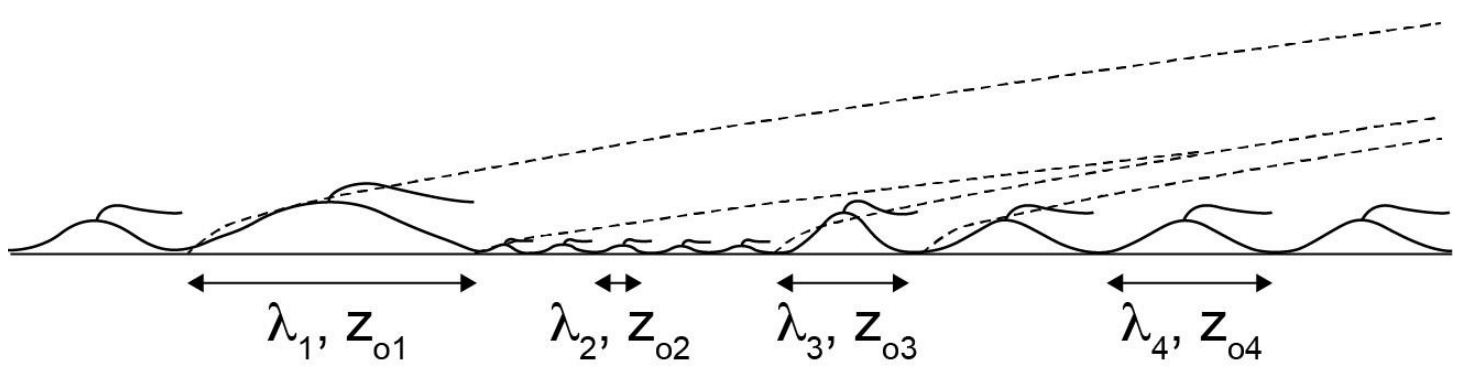

Figure 5 Conceptual basis for hydraulic effects of burrowing at the bank section scale showing the effect of multiple bank protrusions on the near-bank disturbance layer, reproduced from Kean and Smith (2006b). Dashed lines represent the multiple disturbance layers generated by four types of roughness element, with faster growing layers (e.g. $Z_{03}$ ) envelop slower growing layers of smaller elements $\left(\mathrm{Z}_{\mathrm{o} 2}\right)$. Solid lines represent the first part of the wake for each element.

\subsection{Geochemical and biological effects on sediment stability and erodibility}

Geochemical and biological factors also play an important role in determining the stability or erodibility of soils and sediments (particularly cohesive sediments), although these factors are less well understood (Grabowski et al., 2011). The clay fraction in cohesive sediments is the most electrochemically active, characterized by high particle surface area and strong electrochemical charges and, as a result, strongly influences cohesive behavior. These properties mean that the 
chemistry of the pore water, as well as the characteristics of the sediment, influence the erodibility of cohesive banks and margins. Spatial and temporal variations in factors such as temperature, $\mathrm{pH}$ and salinity will therefore influence the stability and erodibility of cohesive aquatic margins and hence the processes discussed in the previous sections (Arulanandan et al., 1971). Microscopic and macroscopic organisms in soils and sediments also have diverse effects on sediment stability including biostabilisation through biofilms and root or fungal networks (Mermillod-Blondin and Rosenberg, 2006; Grabowski et al., 2011; Wilkes et al., 2019) and changes to organic matter content and particle size distributions through feeding and egestion (e.g. Wharton et al., 2006). Again, spatial and temporal variations in these effects will influence the nature and magnitude of processes outlined in the previous sections.

Bioturbating animals increase the mixing of the various constituents of sediment including inorganic particles, organic matter, oxygen and nutrients (Grabowski et al., 2011). Burrowers may, therefore, also influence stability and erosion through changes to geochemical and biological properties of the sediment and pore water. This may include effects associated with burrow construction and maintenance, subsequent exchanges between the burrow and the outer flow, and the non-burrowing effects of burrow occupants, such as feeding and egestion. For example, burrow construction and maintenance has been shown to increase oxidation of sediments through mixing of oxidized and less oxidized sediment, potentially changing the reduction potential of the sediment (Pulmans et al., 2014). Animal burrow networks are also flushed with water originating from the sediment-water interface ('bioirrigation'). This process can significantly influence solute exchange, for example by return of nutrients to the outer flow, and introduction of oxidants into burrows at depth (Miele et al., 2001). The effects of bioturbation on biogeochemical processes, however, depends on the physical (hydrodynamic) properties of the system (Mermillod-Blondin and Rosenberg, 2006). Burrowing has also been linked with the exclusion of plants that might otherwise have a biostabilizing effect on the sediment (e.g. Hughes and Paramour, 2004) and can contribute significantly to the mobilization and transport of fine sediment and increased water turbidity (Harvey et al., 2014; Rice et al., 2016). This generates potential for indirect effects on sediment stability and erodibility through changes to light penetration, water chemistry and aquatic organism health (Harvey et al., 2011). Additional effects of burrowing invaders on the biological factors contributing to sediment erodibility may include consumption of biofilms (Scott et al., 2012), processing of organic matter and alterations to microbial communities (Boeker \& Geist, 2015). Here, we recognize the potential importance of geochemical and biological effects on sediment stability and erodibility in combination with those discussed in sections 4.1 and 4.2 , and emphasize that these will vary spatio-temporally, and according the burrowing species and their wider ecological interactions.

\section{Conclusions and future directions}

Burrowing animals can make numerous contributions to ecosystem functioning, but invasive species can represent a special case as a result of their potential to cause major geomorphic changes and environmental stresses. Concerns over threats to waterways, flood defense infrastructure and waterside landmarks from invasive burrowers are raised in numerous scientific contributions and media reports, but there is a lack of quantitative research on the geophysical impacts. Our review 
explores a range of animals of global interest, including crustaceans, fish, reptiles and mammals. Example species are widely distributed at the global level, and we identify the potential for combined impacts from multiple species in over 20 different countries, states or territories worldwide. The group of species explored is not exhaustive and is intended to illustrate the nature and global relevance of the issue. Furthermore, the current trajectory of global species invasions means that other species of interest will likely emerge in the future. A range of environments are exposed to the impacts of burrowing invasive species, including pond and lake margins, the banks of rivers, creeks and estuaries, salt marsh edges, wetlands, canals and drainage ditches in addition to flood control structures including earthen dams, levees and flood walls.

Using established models of geotechnical, hydrological and hydraulic drivers of bank instability and erosion, we have demonstrated four ways in which burrows can be expected to influence bank stability and erosion. We hypothesize that burrow presence will: (i) alter failure plane position, decrease failure plane length and increase failure plane angle (thereby decreasing bank shear strength) in banks and slopes at aquatic margins; (ii) modify the spatial distribution of pore water pressure, thereby increasing subsurface flow (seepage), reducing cohesion and increasing the likelihood of slip failures at the bank face; (iii) increase turbulence and sediment entrainment at burrow entrances and (iv) alter flow resistance at the bank face. The first three effects are expected to increase bank instability/erosion in most cases, while in contrast higher densities of burrows may increase flow resistance at the bank face, and hence potentially reduce erosion by fluvial action. The density, architecture and positioning of burrows together with the characteristics of the sediment and the hydrodynamic environment will determine the relative importance and interactions of these different effects and, in turn, the net effect on erosion rates. Alongside the geotechnical, hydrological and hydraulic effects of burrows on sediment stability and erosion, burrowing animals may also influence geochemical and biological factors that can contribute to sediment erodibility, including through changes to pore water chemistry and bio-stabilization or destabilization of sediment. As a result of the interacting factors described above, the effects of burrowing invasive species on instability and erosion may include increases, decreases or no significant effects depending on the species and the environment in question. Our conceptual model is applicable beyond invasive species, and may, for example, support investigation of the impacts of native 'pest' species.

Burrowing impacts of invasive species have the potential to generate distal as well as local sediment management issues, including downstream increases in sedimentation arising from increased fine sediment delivery to the river network. The extent and magnitude of distal impacts will depend upon the connectivity of the system as well as the magnitude of site-level sediment inputs. Further research is required to test these hypotheses and quantify the magnitude of impacts in different environments and for different invasive species. Quantification of bank stability and erosion is notoriously challenging as a result of practical limitations of field measurement, high spatial variability and the event-driven nature of the process. However, physical modelling and mesocosm experiments along with numerical modelling of flow hydraulics and slope stability in $3 \mathrm{D}$ can be used to explore the effects of burrow properties (density, morphology/architecture, positioning) on the geotechnical, hydrological and hydraulic processes in different environments. The information on burrow characteristics (e.g. density, morphology) provided in this review can 
be used to inform the design of these experiments. Enclosure/ exclosure field experiments and longer-term monitoring will be required to demonstrate the 'real world' magnitude and significance of changes in erosion rates and associated sediment transfer. Addressing these knowledge gaps will require novel, interdisciplinary approaches to field and modelling studies.

\section{Acknowledgments, Samples, and Data}

The authors would like to thank Ed Oliver in the School of Geography at Queen Mary University of London for help with production of the figures and three reviewers whose constructive comments greatly improved the manuscript. Data available from the authors.

\section{References}

Almeida, D., Argent, R., Ellis, A., England, J., \& Copp, G. H. (2013). Environmental biology of an invasive population of signal crayfish in the River Stort catchment (southeastern England). Limnologica, 43, 177-184.

Aman, J., \& Wilson Grimes, K. (2016). Measuring Impacts of Invasive European Green Crabs on Maine Salt Marshes: A Novel Approach Report to the Maine Outdoor Heritage Fund. Wells National Estuarine Research Reserve.

Angeler, D. G., Sánchez-Carillo, S., García, G., \& Alvarez-Cobelas, M. (2001). The influence of Procambarus clarkii (Cambaridae, Decapoda) on water quality and sediment characteristics in a Spanish floodplain wetland. Hydrobiologia, 464, 89-98.

Arulanandan, K., Gillogley, E. and Tully, R., 1980. Development of a Quantitative Method to Predict Critical Shear Stress and Rate of Erosion of Natural Undisturbed Cohesive Soils. California University Davis, Department of Civil Engineering Technical Report GL-80-5.

Bailey, D. R., Dittbrenner, B. J. \& Yocom, K. P. (2018) Reintegrating the North American beaver (Castor Canadensis) in the urban landscape. WIREs Water 6: e1323.

Barbaresi, S., Tricarico, E., \& Gherardi, F. (2004). Factors inducing the intense burrowing activity of the red-swamp crayfish, Procambarus clarkii, an invasive species. Naturwissenschaften, 91, 342-345.

Bayoumi A. and Meguid M. A. (2011) Wildlife and safety of earthen structures: a review. Journal of Failure Analysis and Prevention. DOI 10.1007/s11668-011-9439-y

BBC News. (2018). Bath's Prior Park crayfish damage to 'cost millions' [web page]. BBC News. Retrieved from https://www.bbc.co.uk/news/uk-england-somerset-44314534 on 27/11/2018. 
Bertoldi, W., Gurnell, A. M., Drake, N. A. 2011. The topographic signature of vegetation development along a braided river: Results of a combined analysis of airborne lidar, color air photographs, and ground measurements. Water Resources Research 47: W06525.

Bertolino, S., \& Genovesi, P. (2007). Semiaquatic mammals introduced into Italy: case studies in biological invasion (pp. 175-191). In F. Gherardi (Ed.), Biological invaders in inland waters: Profiles, distribution, and threats. Dordrecht, The Netherlands: Springer.

Blouin, M., Hodson, M. E., Delgado, E. a>, Baker, G., Brussard, L., Butt, K. R., Dai, J., Dendooven, L., Peres, G., Tondoh, J. E., Cluzeau, D. \& Brun, J.-J. (2013) A review of earthworm impact on soil function and ecosystem services. European Journal of Soil Science 64: 161-182.

Boeker, C. \& Geist, J. (2015) Effects of invasive and indigenous amphipods on physicochemical and microbial properties in freshwater substrates. Aquatic Ecology 49: 467-480.

Boltovsky, D., Sylvester, F. \& Paolucci, E. M. (2018) Invasive species denialism: sorting out facts, beliefs and definitions. Ecology and Evolution 8: 11190-11198.

Bouma, S., \& Soes, D. M. (2010). A risk analysis of the Chinese mitten crab in The Netherlands. Report commissioned by the Ministry of Agriculture, Nature and Food Quality, Team Invasive Alien Species. Report number 10-025.

Butler, D. R. (1995) Zoogeomorphology. Cambridge University Press, Cambridge, UK.

Butler, D. R., Anzah, F., Goff, P. D., \& Villa, J. (2018). Zoogeomorphology and resilience theory. Geomorphology, 305, 154-162.

Byers, J. E., Cuddington, K., Jones, C. G., Talley, T. S., Hastings, A., Lambrinos, J. G., Crooks, J. A. \& Wilson, W. G. (2006) Using ecosystem engineers to restore ecological systems. Trends in Ecology and Evolution 9: 493-500.

Carson, M. A. and Kirkby, M. J. (1972) Hillslope Form and Process. Cambridge University Press, New York.

Carter, J., \& Leonard, B. P. (2002). A review of the literature on the worldwide distribution, spread of, and efforts to eradicate the Coypu (Myocastor coypus). Wildlife Society Bulletin, 30, $162-175$.

Casagli, N., Rinaldi, M., Gargini, A., \& Curini. A. (1999). Pore water pressure and streambank stability: results from a monitoring site on the Sieve River, Italy. Earth Surface Processes and Landforms, 24, 1095-1114. 
Clark, P. F., Rainbow, P. S., Robbins, R. S., Smith, B., Yeomans, W. E., Thomas, M., \& Dobson, G. (1998). The alien Chinese mitten crab, Eriocheir sinensis (Crustacea: Decapoda: Brachyura), in the Thames catchment. Journal of the Marine Biology Association UK, 78, 12151221.

Correia, A. M., \& Ferreira, O. (1995). Burrowing behavior of the introduced red swamp crayfish Procambarus clarkii (Decapoda:Cambaridae) in Portugal. Journal of Crustacean Biology, 15, 248-257.

Coverdale, T. C., Axelman, E. E., Brisson, C. P., Young, E. W., Altieri, A. H., Bertness, M. D. (2013) New England Salt Marsh Recovery: Opportunistic Colonization of an Invasive Species and Its Non-Consumptive Effects. PLoS ONE 8(8): e73823.

Crooks, J. A. (2002) Characterizing ecosystem-level consequences of biological invasions: the role of ecosystem engineers. Oikos 97: 153-166.

DAISIE. (2019). Delivering Alien Invasive Species Inventories for Europe [Website]. Retrieved from http://www.europe-aliens.org on 15/04/2019.

Darby, S. E., \& Thorne, C. R. (1994). Prediction of tension crack location and riverbank erosion hazards along destabilised channels. Earth Surface Processes and Landforms, 19, 233-245.

Darby, S. E., \& Thorne, C. R. (1996). Development and testing of riverbank stability analysis. Journal of Hydraulic Engineering, 122, 433-454.

Davidson, T. (2008). Prevalence and Distribution of the Introduced Burrowing Isopod, Sphaeroma quoianum, in the Intertidal Zone of a Temperate Northeast Pacific Estuary (Isopoda, Flabellifera) Crustaceana, 81(2), 155-167.

Davidson, T. M., \& de Rivera, C. E. (2010). Accelerated erosion of saltmarshes infested by the non-native burrowing crustacean Sphaeroma Quoianum. Marine Ecology Progress Series, 419, 129-136.

Davidson, T. M., \& de Rivera, C. E. (2012). Per capita effects and burrow morphology of a burrowing isopod (Sphaeroma Quoianum) in different estuarine substrata. Journal of Crustacean Biology, 32, 25-30.

Davidson, T. M., Altieri, A. H., Ruiz, G. M. and Torchin, M. E. (2018) Bioerosion in a changing world: a conceptual framework. Ecology Letters 21: 422-438.

Davis, M. A., Chew, M. K, Hobbs, R. J. et al. (2011) Don't judge species on their origins. Nature 474: 153-154.

Dorgan, K. M. (2015). The biomechanics of burrowing and boring. The Journal of Experimental Biology, 218, 176-183. 
Early, R., Bradley, B. A., Dukes, K., Lawler, J. J., Olden, J. D., Blumenthal, D. M., et al. (2016). Global threats from invasive alien species in the twenty-first century and national response capacities. Nature Communications, 7, 12485. https://doi.org/10.1038/ncomms 12485

Faller, M., Harvey, G. L., Henshaw, A. J., Bertoldi, W., Bruno, M. C. \& England, J. (2016). River bank burrowing by invasive crayfish: spatial distribution, biophysical controls and biogeomorphic significance. Science of the Total Environment, 569-570, 1190-1200. https://doi.org/10.1016/j.scitotenv.2016.06.194

Faulkner, H. (2006). Piping hazard on collapsible and dispersive soils in Europe (pp. 537-562). In J. Boardman \& J. Poesen (Eds.), Soil Erosion in Europe. Chichester: John Wiley \& Sons Ltd. Federal Emergency Management Agency. (2003). Report on Speciality Workshop 1: Plant and Animal Impacts on Earthen Dams. Reports to FEMA on Future Research Needs in Dam Safety. Asc. Of State Dam Safety Officials Inc. Lexington, KY, USA.

Federal Emergency Management Agency. (2003). Impacts of Plants and Animals on Earthen Dams. Future Research Needs in Dam Safety Series. US Department of Homeland Security.

Fei, S., Phillips, J., \& Shouse, M. (2014). Biogeomorphic impacts of invasive species. Annual Review of Ecology, Evolution and Systematics, 45, 69-87.

Ferriter, A., Doren, B., Winston, R., Thayer, D., Miller, B., Thomas, B., et al. (2008). Chapter 9: The Status of Nonindigenous Species in the South Florida Environment. In South Florida Environmental Report Volume 1: The South Florida Environment.

Fox, G. A., \& Wilson, G. V. (2010). The role of subsurface flow in hillslope and stream bank erosion: a review. Soil Science Society of America Journal, 74, 717-733.

Fredlund, D. G., \& Rahardjo, H. (1993). Soil Mechanics for Unsaturated Soils. New York: John Wiley \& Sons Ltd.

Gallardo, B., Clavero, M., Sánchez, M. I., \& Vilà, M. (2016). Global ecological impacts of invasive species in aquatic ecosystems. Global Change Biology 22: 151-163.

GBNNSS (2019) GB Non-native Species Secretariat [website]. Available at: http://www.nonnativespecies.org/home/index.cfm. Accessed 17/04/2019.

GISD. (2019). Global Invasive Species Database [website] Retrieved from http://www.iucngisd.org/gisd/search.php on 15/04/2019.

Grabowski, R. C., Droppo, I. G. and Wharton, G. (2011) Erodability of cohesive sediment: the importance of sediment properties. Earth-Science Reviews 105: 101-120. 
Guan, R. Z. (1994). Burrowing behaviour of signal crayfish, Pacifastacus leniusculus (Dana), in the River Great Ouse, England. Freshwater Forum, 4, 155-168.

Hagerty, D.J. (1991a). Piping/sapping erosion. I: Basic considerations. Journal of Hydraulic Engineering 117(8), pp.991-1008

Hagerty, D.J. (1991b). Piping/sapping erosion. II: Identification-diagnosis. Journal of Hydraulic Engineering 117(8): 1009-1025.

Hanfling, B., Edwards, R., \& Gherardi, F. (2011). Invasive alien Crustacea: dispersal, establishment, impact and control BioControl, 56, 573-595.

Harvey, G. L., Moorhouse, T. M., Clifford, N. J., Henshaw, A. J., Johnson, M. F., Macdonald, D. W., et al. (2011). Evaluating the role of invasive aquatic species as drivers of fine sedimentrelated river management problems: the case of the signal crayfish (Pacifastacus leniusculus). Progress in Physical Geography, 35, 517-533.

Harvey, G. L., Henshaw, A. J., Moorhouse, T. P., Clifford, N. J., Holah, H., Grey, J. and Macdonald, D. W. (2014) Invasive crayfish as drivers of fine sediment dynamics in rivers: field and laboratory evidence. Earth Surface Processes and Landforms 39: 259-271.

Haussman, N. S. (2017). Soil movement by burrowing mammals: A review comparing excavation size and rate to body mass of excavators. Progress in Physical Geography, 41, 29-45. Herborg, L-M., Rushton, S. P., Clare, A. S., \& Bentley, M. G. (2003). Spread of the Chinese mitten crab (Eriocheir sinensis H. Milne Edwards) in Continental Europe: analysis of a historical data set. Hydrobiologia, 503, 21-28.

Herborg, L-M., Rushton, S. P., Clare, A. S. \& Bentley, M. G. (2005). The invasion of the Chinese mitten crab (Eriocheir sinensis) in the United Kingdom and its comparison to continental Europe. Biological Invasions, 7, 959-968.

Hobbs R. J., Higgs, E. and Harris, J. A. (2009) Novel ecosystems: implications for conservation and restoration. Trends in Ecology and Evolution 24: 599-605.

Holdich, D. M. (1999). The negative effects of established crayfish introductions (pp. 221-236). In F. Gherardi \& D. M. Holdich (Eds.), Crayfish in Europe as Alien Species: How to Make the Best of a Bad Situation? Balkema: Rotterdam.

Hong, S., Do, Y., Kim, J. Y., Kim, D-K., \& Joo, G-J. (2015). Distribution, spread and habitat preferences of nutria (Myocastor coypus) invading the lower Nakdong River, South Korea. Biological Invasions, 17, 1485-1496. 
Hoover, J. J., Kilgore, K. J., \& Cofrancesco, A. F. (2004). Suckermouth catfishes: threats to aquatic ecosystems of the United States? Aquatic Nuisance Species Research Program Bulletin, 4, 1-9.

Hughes, R. G. \& Paramor, O. A. L. (2004) On the loss of saltmarshes in south-east England and methods for their restoration. Journal of Applied Ecology 41: 440-448.

Jackson, T. R., Apte, S. V., Haggerty, R., \& Budwig, R. (2015) Flow structure and mean residence times of lateral cavities in open channel flows: influence of bed roughness and shape. Environmental Fluid Mechanics, 15, 1069-1100.

Jones, C. G., Lawton, J. H. \& Shachak, M. (1994) Organisms as ecosystem engineers. Oikos 69: 373-386.

Kean, J. W., \& Smith, J. D. (2006a). Form drag in rivers due to small-scale natural topographic features: 1. Regular sequences. Journal of Geophysical Research: Earth Surface, 111, F04009.

Kean, J. W., \& Smith, J. D. (2006b). Form drag in rivers due to small-scale natural topographic features: 1. Irregular sequences. Journal of Geophysical Research: Earth Surface, 111, F04010.

Kean, J. W., Kuhnle, R. A., Smith, J. D., Alonson, C. V., \& Langendoen, E. J. (2009). Test of a method to calculate near-bank velocity and boundary shear stress. Journal of Hydraulic Engineering, 135, 588-601.

Kern, W. H. (2004). Dealing with iguanas in the South Florida landscape. Entomology and Nematology Department, UF/IFAS Extension. Report number ENY-714.

Krysko, K. L., Enge, K. M., Donlan, E. M., Seitz, J. C., \& Golden, E. A. (2007). Distribution, natural history, and impacts of the introduced green iguana (Iguana iguana) in Florida. Iguana, $14,143-151$.

Lawler, D. M., Thorne, C. R., \& Hooke, J. M. (1997). Bank erosion and instability (pp. 137172). In C. R. Thorne, R. D. Hey \& M. D. Newson (Eds.), Applied Fluvial Geomorphology for River Engineering and Management. John Wiley \& Sons Ltd: Chichester.

Leyland, J., Darby, S.E., Teruggi, L., Rinaldi, M., \& Ostuni, D. (2015). A self-limiting bank erosion mechanism? Inferring temporal variations in bank form and skin drag from high resolution topographic data. Earth Surface Processes and Landforms, 40, 1600-1615.

Lienhart, G-D. H., Rodiles-Hernandez, R., \& Capps, K. A. (2013). Nesting Burrows and Behavior of Nonnative Catfishes (Siluriformes: Loricariidae) in the Usumacinta-Grijalva Watershed, Mexico. The Southwestern Naturalist, 58, 238-243.

Lindow, N., Fox, G.A. \& Evans, R.O., 2009. Seepage erosion in layered stream bank material. Earth Surface Processes and Landforms, 34(12): 1693-1701 
Loureiro, T. G., Silva Gentil Anastácio, P. M., Araujo, P. B., Souty-Grosset, C., \& Almerão, M. P. (2015). Red swamp crayfish: biology, ecology and invasion - an overview. Nauplius, 23, 1-19.

Meile, T., Boilat, J-L., \& Schleiss, A. J. (2011). Flow Resistance Caused by Large-Scale Bank Roughness in a Channel. Journal of Hydraulic Engineering, 137, 1588-1597.

Meetenmeyer, R. K., Vogler, J. B., \& Butler, D. R. (1998). The geomorphic influences of burrowing beavers on streambanks, Bolin Creek, North Carolina. Zeitschrift für Geomorphologie, 42, 453-468.

Meile, C., Korestsky, C. M. \& Van Cappellen, P. (2001) Quantifying bioirrigation in aquatic sediments: an inverse modelling approach. Limnology and Oceanography 46: 164-177.

Mermillod-Blondin, F. and Rosenberg, R. (2006) Ecosystem engineering: the impact of bioturbation on biogeochemical processes in marine and freshwater benthic habitats. Aquatic Sciences 68: 434-442.

Moorhouse, T. P., \& Macdonald, D. W. (2015). Are invasives worse in freshwater than terrestrial ecosystems? WIREs Water, 2, 1-8. https://doi.org/10.1002/wat2.1059

Naylor, L. G., Jelks, H. L. \& Tuten, T. (2009) Biogeomorphology revisted: looking towards the future. Geomorphology 47: 3-14.

Nico, L. G., Jelks, H. L., \& Tuten, T. (2009). Non-native suckermouth armored catfishes in Florida: description of nest burrows and burrow colonies with assessment of shoreline conditions. Aquatic Nuisance Species Research Program Bulletin, 9, 1-30/ NOBANIS. (2019). European Network on Invasive Alien Species [Website]. Retrieved from https://www.nobanis.org/ on 15/04/2019.

Onda, Y., \& Itakura, N. (1997). An experimental study on the burrowing activity of river crabs on subsurface water movement and piping erosion. Geomorphology, 20, 279-288.

Orlandini, S., Moretti, G., \& Albertson, J. D. (2015). Evidence of an emerging levee failure mechanism causing disastrous floods in Italy. Water Resources Research, 51, 7995-8011. https://doi.org/10.1002/2015WR017426

Ozalp, C., Pinarbasi, A., \& Sahin, B. (2010). Experimental measurement of flow past cavities of different shapes. Experimental Thermal and Fluid Science, 34, 505-515.

Panning, A. (1938). The Chinese mitten crab (pp. 361-376). In Annual report of the Board of Regents of the Smithsonian Institution. United States Government Printing Office: Washington. 
Panzacchi, M., Cocchi, R., Genovesi, P., \& Bertolino, S. (2007). Population control of coypu Myocastor coypus in Italy compared to eradication in UK: a cost-benefit analysis. Wildlife Biology, 13, 159-171.

Parker, I., Simberloff, D., Lonsdale, W., Goodell, K., Wonham, M., Kareiva, P. M., Williamson, M. H., Von Holle, B., Moyle, P. B., Byers J. E., and Goldwasser, L. (1999) Impact: Toward a Framework for Understanding the Ecological Effects of Invaders. Biological Invasions 1: 3-19.

Polvi L. E. and Sarneel, J. M. (2017) Ecosystem engineers in rivers: An introduction to how and where organisms create positive biogeomorphic feedbacks. WIREs Water 5: e1271.

Pülmanns, N., Diele, K., Mehlig, U., Nordhaus, I. (2014) Burrows of the Semi-Terrestrial Crab Ucides cordatus Enhance CO2 Release in a North Brazilian Mangrove Forest. PLoS ONE 9(10): e109532.

Pimental, D., McNair, S., Janecka, J., Wightman, J., Simmonds, C., O’Connell, C., et al. (2001). Economic and environmental threats of alien plant, animal, and microbe invasions. Agriculture, Ecosystems and Environment, 84, 1-20.

Reinhardt, L., Jerolmack, D., Cardinale, B. J., Vanacker, V. and Wright, J. (2010) Dynamic interactions of life and its landscape: feedbacks at the interface of geomorphology and ecology. Earth Surface Processes and Landforms 35: 78-101.

Rice, S. P., Johnson, M. F., Reid, I. (2012). Animals and the geomorphology of gravel-bed rivers. In Church, M, Biron, PM, Roy, AG (ed) Gravel-bed Rivers: Processes, Tools, Environments, John Wiley \& Sons, pp.225-241, ISBN: 9780470688908.

Rice, S. P., Johnson, M. F., Mathers, K., Reeds, J. \& Extence, C. (2016) The importance of biotic entrainment for base flow fluvial sediment transport. Journal of Geophysical Research: Earth Surface 121: 890-906.

Rinaldi, M., \& Darby, S. E. (2007). Modelling river-bank-erosion processes and mass failure mechanisms: progress towards fully coupled simulations (pp. 213-239). In H. Habersack, H. Piegay \& M. Rinaldi (Eds.), Gravel-Bed Rivers VI: From Process Understanding to River Restoration. Elsevier Science: Amsterdam.

Rudnick, D. A., Halat, K. M., \& Resh, V. H. (2000). Distribution, Ecology and Potential Impacts of the Chinese Mitten Crab (Eriocheir sinensis) in San Francisco Bay. Department of Environmental Science, Policy and Management University of California, Berkeley. Technical Completion Report number UCAL-WRC-W-881.

Rudnick, D. A., Hieb, K., Grummer, K. F., \& Resh, V. H. (2003). Patterns and processes of biological invasion: The Chinese mitten crab in San Francisco Bay. Basic Applied Ecology, 4, 249-262. 
Rudnick, D. A., Chan V., \& Resh, V. H. (2005). Morphology and impacts of the burrows of the Chinese mitten crab, Eriocheir sinensis H. Milne Edwards (Decapoda: Grapsoidea), in south San Francisco Bay, California, USA. Crustaceana, 78, 787-807.

Ruiz G., Fofonoff P., Steves B. \& Dahlstrom A. (2011) Marine Crustacean Invasions in North America: A Synthesis of Historical Records and Documented Impacts. In: Galil B., Clark P., Carlton J. (eds) In the Wrong Place - Alien Marine Crustaceans: Distribution, Biology and Impacts. Invading Nature - Springer Series in Invasion Ecology, vol 6. Springer, Dordrecht

Russell, J. C. (2012) Do invasive species cause damage? Yes. Bioscience 62(3): 217.

Scott, S. E., Pray, C. L., Nowlin, W. H. and Zhang, Y. (2012) Effects of native and invasive species on stream ecosystem functioning. Aquatic Sciences 74: 793-808.

Seebens, H., Blackburn, T. M., Dyer, E. E., Genovesi, P., Hulme, P.E., \& Jeschke, J. M. (2017). No saturation in the accumulation of alien species worldwide. Nature Communications, 8, 14435. https://doi.org/10.10.38/ncomms14435

Sementelli, A., Smith, H. T., Meshaka Jr, W. E., \& Engeman, R. M. (2008). Just Green Iguanas? The associated costs and policy implications of exotic invasive wildlife in South Florida. Public Works Management and Policy, 12, 599-606.

Simberloff, D. (2011) Non-natives: 141 scientists object. Nature 475: 36.

Simon, A., Curini, A., Darby, S. E., \& Langendoen, E. J. (2000). Bank and near-bank processes in an incised channel. Geomorphology, 35, 193-217.

Simon, A., \& Curini, A. (1998). Pore pressure and bank stability: The influence of matric suction (pp. 358-363). In S. Abt (Ed.), Hydraulic Engineering 1998. ASCE: Reston.

Sofia, G., Masin, R., \& Tarolli, P. (2016). Prospects for crowdscourced information on the geomorphic 'engineering' by the invasive Coypu (Myocastor coypus). Earth Surface Processes and Landforms, 42, 365-377.

Stebbing, P. D., Londshaw, M., Taylor, N., Norman, R., Lintott, R., Pearce, F., \& Scott, A. (2012). Review of methods for the control of invasive crayfish in Great Britain. Cefas Final Report C5471.

Talley, T. S., Crooks, J. A., \& Levin, L. A. (2001). Habitat utilization and alteration by the invasive burrowing isopod, Sphaeroma quoyanum, in California salt marshes. Marine Biology, $138,561-573$. 
Telegraph Reporters. (2016). Invasive crayfish threaten Oxford college [Web page]. The Telegraph. Retrieved from https://www.telegraph.co.uk/education/2016/08/11/invasivecrayfishthreaten-oxford-college/ on 27/11/2018.

Terzaghi, K., Peck, R.B. and Mesri, G., 1996. Soil mechanics in engineering practice. John Wiley \& Sons.

Thorne, C. R. (1982). Processes and mechanisms of river bank erosion. In Hey, R. D., Bathurst, J. C. \& Thorne, C. R. (Eds.), Gravel-bed Rivers. John Wiley and Sons, Chichester, pp. 227-271.

UN Convention on Biological Diversity (2019) Convention on Biodiversity [website]. Available at: https://www.cbd.int/. Accessed 11/04/2019.

Valery, L., Fritz, H. and Lefeuvre, J.-C. (2013) Another call for the end of invasion biology. Oikos 122: 1143-1146.

Van den Ende, O. (2014). Burrowing by Sailfin Catfish (Pterygoplichthys sp.): A potential cause of erosion in disturbed environments. Aquatic Nuisance Species Research Program. ERDC/TN ANSRP-14-1.

Vila, M., Basnou, C., Pysvek, P., Josefsson, M., Genovesi, P., Gollasch, S., et al. (2010). How well do we understand the impacts of alien species on ecosystem services? A pan-European, cross-taxa assessment. Frontiers in Ecology and the Environment, 8, 135-144.

Washington State Department of Fish and Wildlife. (2006). Living with Wildlife: Beavers [website]. Retrieved from https://wdfw.wa.gov/living/beavers.html on 27/11/2018.

Wallentinus, I., \& Nyberg, C. D. (2007). Introduced marine organisms as habitat modifiers. Marine Pollution Bulletin, 55, 323-332.

Wilkes, M. A., Gittens, J. R., Mathers, K. L., Mason, R., Casa-Mulet, R., Vanzo, D., Mckenzie, M., Murray-Bligh, J., England, J., Gurnell, A. \& Jones, J. I. (2019) Physical and biological controls on fine sediment transport and storage in rivers. WIREs Water 6: e1331.

Wilkinson, M. T., Richards, P. J., \& Humphreys, G. S. (2009). Breaking ground: pedological, geological and ecological implications of soil bioturbation. Earth Science Reviews, 97, 257-272.

Williams, F., Eschen, R., Harris, A., Djeddour, D., Pratt, C., Shaw, R. S., et al. (2010). The economic cost of invasive non-native species on Great Britain. CABI Europe - UK. Surrey. CABI Project Number VM10066.

Wolff, L. M. (2002). Why alien invaders succeed: Support for the Escape-from-Enemy Hypothesis. American Naturalist, 160, 705-711. 
Xin, P., Guangqiu, J., Li, L., \& Barry, D. A. (2009). Effects of crab burrows on pore water flows in salt marshes. Advances in Water Resources, 32, 439-449. 